\title{
高齢者の心理概念モデルに基づく移動支援機器開発要件の抽出*
}

\author{
二 瓶 美 里*1, 井上 剛 伸*2, 望月 美栄子*3 \\ 八巻 知香子*4, 楠 永 敏 恵 ${ }^{* 5}$, 藤 江 正 克 ${ }^{* 1}$
}

\section{Proposition of Development Concept of Mobility Aids Based on Psychological Model of Older Persons}

\author{
Misato NIHEI*6, Takenobu INOUE, Mieko MOCHIZUKI, \\ Chikako YAMAKI, Toshie KUSUNAGA and Masakatsu G. FUJIE \\ ${ }^{* 6}$ Department of Bioscience and Biomedical Engineering, Waseda University, \\ 3 Okubo, Shinjuku-ku, Tokyo, 169-8555 Japan
}

\begin{abstract}
The development of assistive technologies has an important impact on the user's activities of daily living and social participation. However, assistive technology identifies persons with disabilities. In this paper, the psychological effects of using a mobility aid were considered before forming the concept of a new device. To identify detrimental factors, a qualitative research approach was adopted in a study on 12 older persons. The investigation revealed that older persons had a dilemma in using mobility aids between maintaining body functions and extending mobility activities. In addition, there are two sides to the dilemma, the function and the image of the body. The process to assuage these dilemmas was clarified and a psychological model was built up. The generation process of the psychological conflict obtained from qualitative data was revealed by modeling details and taking movement, body function and body appearance into consideration. Development of useful assistive technology will be improved by taking account of compositive observational study on the body, the life and the psychological situation of older persons.
\end{abstract}

Key Words: Medical and Welfare Assistance, Design Engineering, Mobility Aid, Qualitative Research, Product Development, Psychological Model

\section{1. 粕 言}

日本における福祉機器の市場は 1993 年の福祉用具 法制定以降, 社会・産業・利用者に対し重要な意義を 持つ市場であるとされ, 成長産業と称されてきた. そ の後, 2000 年の介護保険制度などによる社会システム の改変もあり, 市場規模は拡大し, 現在は成熟期とい われている(1). このように, 福祉機器の利用を促進す る社会基盤が整うことで, 機器の標準化や規格化が進 み, この十数年で品質が向上し, 安全性・操作性など も重視されるようになった.

福祉機器は, 利用者側の立場から見ると身体状況や 生活状況に加え, 心理的な効果も期待される機器であ る.これまで, 重度障害者を対象とした当事者参加型 の開発事例からは, 福祉機器が身体・生活・心理に総 合的に影響を与えることが明らかにされてきた ${ }^{(2)}$.こ

* 原稿受付 2006 年 5 月 11 日.

*1 正員, 早稲田大学理工学研究科(画169-8555 東京都新宿区 大久保 3)

*2 正員, 国立身体障害者りハビリテーションセンター研究所 (恵359-8555 所沢市並木 4).

*3 東京大学大学院医学系研究科 ( $\mathbf{W}$ 113-0033 東京都文京区本 郷 7).

*4 日本学術振興会 (焉 359-8555 所沢市並木 4).

$* 5$ 聖徳大学短期大学部 (画 271-8555 松戸市岩瀬 550).

E-mail : mnihei@asagi.waseda.jp
の当事者参加型の開発手法は，当事者（利用者）が開 発の過程で心理状況を含さへーズ情報を, 直接開発者 に伝えることが可能であるという特徴を持つ.このよ うな開発の初期段階でニーズを的確に捉える手法は, 福祉機器を開発する上で重要であることが示されて いる(3).

福祉機器が普及してきている一方で, 福祉機器は機 器自体が「機器を使う人は障害者である」というステ イグマの意味合いを含み，それを利用することが心理 的なストレスを生む場合がある.これまで，そのよう な心理的なストレスを軽減する方法は，主に社会福祉 分野においては周辺意識の改革 ${ }^{(4)}$ ，あるいは臨床現場 における介入アプローチ(5) という形で提案, 検討され てきた. しかし，そのストレスは機器に付随するもの であるため, 機器開発の初期段階で開発者が心理的な ストレスを理解し，軽減する方策を取り入れることが 有効であると考えられるが，そのような観点で進めら れた機器開発の事例はほとんど存在しない.つまり, 心理的なストレスに関する評価を機器開発プロセス ${ }^{(6)}$ の中でフィードバックさせることが注目されてこな かったのである. 
本研究の目的は, 福祉機器を利用することで発生す る心理的なストレスを, 開発の初期段階で事前に考慮 し, 新たな機器の開発要件を抽出することである. 本 研究では, 最も代表的な福祉機器である移動支援機器 に着目した. まず，高齢者が車いすなどの機器をどの ように捉え，どのような印象を持っているかを把握す るために，個人個人のより心理的に深い情報を捉える ことのできる質的研究アプローチを用い, 調査を行っ た. 次に, その調查結果から, 調査協力者である高齢 者の心理状況を可視化し, 心理的なストレスの要因を 明確化した. さらに，そのストレスを軽減する新たな 移動支援機器の開発要件の抽出と提案を行った.

\section{2. 高秢者と移動支援機器}

$2 \cdot 1$ 質的研究アプローチ(7)(8)の導入 質的研究ア プローチは, 心理学, 人文学, 社会心理学などで用い られる手法であり， 口述データを基に理論を構築する 手法である. この手法は, 定性的に得られた情報をボ トムアップ的に集計するため, あらかじめ項目を設定 したアンケート手法や統計的な手法と異なり, より梁 い情報や，心理的な現象を把握しやすい特徴を持つ. インタビュー時に記録した口述データは, はじめに テキストデータに変換し, 発言ごとに通し番号を付け る. 次に調查協力者の発言を文脈ごとに整理し, ラベ ル付けを行う。ここでは取得したテキストデータを生 データとして取り扱い，口述的な発言者固有の表現を そのまま記載する方法をとる.これにより, データマ イニングなどの言語分析の手法では示すことのでき ない, 発言者の文脈上に現れる悩み, 喜び, 葛藤など の詳細を把握することができる.

$2 \cdot 2$ 質的研究アプロ一チと概念設計 機器開発に おける本アプローチは, 設計の初期段階で重要な役割 を持つ概念設計の際に用いることができる.つまり， 高齢者の視点から得られる質的なデータを, 設計の上 流過程において考慮することができれば，心理的な影 響などを事前に考慮した機器開発が可能となる (図 1). そのため, 本研究では具体的な事例として, 高齢者と 移動支援機器に焦点を絞り, 調査を行うこととした.

$2 \cdot 3$ 調查対象の設定 図 2 に調查協力者の分類 を示す．本論文では高齢者を 65 歳以上の男女と定義 し, 移動方法と身体状況について分類する. 移動方法 に関しては, 日常的に車いすを利用していない高龄者 を車いす非利用者, 利用している高齢者を車い寸利用 者とする. 身体機能に関しては, 何らかの障害のある 場合には高齢障害者, それ以外を健常高齢者と称する. 一方, 調查の対象とする移動支援機器は, 日常の生 活や活動に用いられる身近な機器とし, 主に病院等に 設置されている折りたたみ車いす, 外出用の杖, 4 輪

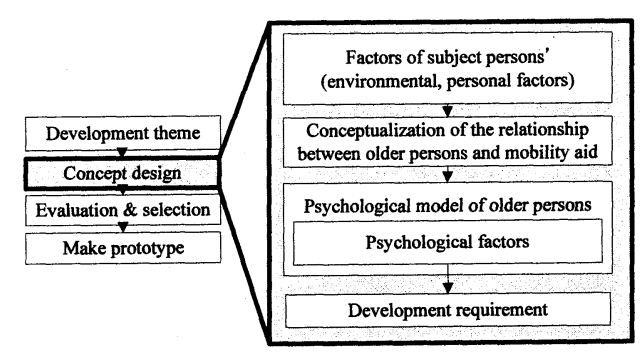

Fig. 1 Introduction of qualitative research approach for concept design

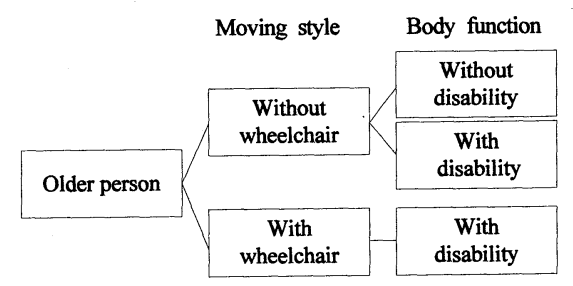

Fig. 2 Classification of participants

Table 1 Typical personal mobility aids in daily living ${ }^{(9)}$

\begin{tabular}{|c|c|c|}
\hline Mobility Aid & Device Function & Body Function \\
\hline Walking-stick & $\begin{array}{l}\text { Walking-aids with } \\
\text { one leg and a } \\
\text { handle without } \\
\text { forearm support. }\end{array}$ & $\begin{array}{l}\text { Person for whom } \\
\text { support when } \\
\text { walking is } \\
\text { necessary. The } \\
\text { person grasps the } \\
\text { stick to support } \\
\text { their weight. }\end{array}$ \\
\hline Rollators & $\begin{array}{l}\text { Wheeled frames } \\
\text { with built - in } \\
\text { handgrips and legs, } \\
\text { which provide } \\
\text { support whilst } \\
\text { walking. }\end{array}$ & $\begin{array}{l}\text { Person who needs } \\
\text { greater support } \\
\text { and stability than } \\
\text { using a stick. }\end{array}$ \\
\hline $\begin{array}{l}\text { स्थ } \\
\text { Wheelchair }\end{array}$ & $\begin{array}{l}\text { Wheelchairs } \\
\text { designed to be } \\
\text { propelled by the } \\
\text { user, by pushing } \\
\text { with both hands on } \\
\text { the rear wheels or } \\
\text { on the hand rims } \\
\text { of the rear wheels. }\end{array}$ & $\begin{array}{l}\text { Person who can } \\
\text { walk for short } \\
\text { periods. }\end{array}$ \\
\hline
\end{tabular}

の歩行器とした. それらの機器の機能的な特徴と主な 利用者の身体機能の特徵を表 1 に示す.

\section{3. 調査方法}

$3 \cdot 1$ 調查協力者 福祉機器は一般製品と異なり, 利用者の個人因子や環境因子によって同種類・同機能 の機器であっても, その印象がポジティブからネガテ イブまで幅広く分布していると言われている(10). また， 利用年数や障害の違い（先天性・後天性）によって機 器の捉え方が異なる傾向があることを指摘している 調査研究もある(11)。そのため, 本調查では機器を利用 
中の高齢者に対してのみの調査ではなく，機器を利用 する以前の高齢者が持つ機器の印象などを知る必要 があると考えた。

表 2 に調査協力者 12 名のプロフィール（属性 Attribute, 身体状況·病歴 Physical Status and Disease, 日 常生活・習慣 Daily Life/Routine, 要介護度 Care Need, 移動支援機器利用の経験 Experience in Use of Mobility Aids)および特徴を示す.協力者の平均年齢は 77.5 歳, 男性 4 名, 女性 8 名である. 機器を利用しない健常高 齢者（A-F）は，歩行を中心とした移動を行う在宅生 活者であり，うち 3 名は腰・背痛がある. 高歯障害者 G は，過去に車い寸利用の経験があるが，現在は装具 と歩行器を用いた歩行を行っており, 週 2 回デイサー ビスを利用している．高齢障害者（H-L）は，デイサ ービスに車かバスで週 2 回通所する要介護度 1 から 3 の車い寸利用者であり，配偶者や子供と生活している. またKは日常生活では車いすを利用し, 施設内では歩 行器を用いた歩行を行っている.

$3 \cdot 2$ インタビュー方法 インタビュ一調査は原 則として調査協力者の自宅, デイサービス等の介護施 設の個室や静かな場所で行った. 調査者は著者本人と 数名で構成し, 威圧感のない服装や言動に心がけた. はじめに, プロフィールを作成するための個人因子や 環境因子となる身体状況や生活状況の聞き取り調査 を行った. その後, 移動と歩行, 生活やそれらに利用 する移動支援機器に関する直接対面式の半構造化面 接を行った. 調査項目は, 属性, 移動, 活動, 生活圈, 現在の自分自身の身体状況についての認識, 機器の使
用経験, 機器への要望, 目指寸ライフスタイル, 歩行 などが含まれる.インタビューは2004年 8 月から 2005 年 5 月, 12 名の協力者に対して実施した. 平均所要時 間は約 110 分, 1 名につき 1 回の調査を行った.

$3 \cdot 3$ デ一タの取得方法 本調查では協力者の同 意のもとで，インタビューデータの会話を IC レコー ダで記録し，逐語録を作成した. 調査の分析には社会 状況の分析手法 ${ }^{(12)}$ を参考にし，個人のプロフィールの 作成および逐語録中の機器に関する部分の抽出を行 った. その後, 逐語録を読み返すことで機器に対する 印象と実感, 個人ごとの印象の変化や考え方とプロフ イールの関連性を把握した.

\section{4. 調査結果 · 考察}

\section{$4 \cdot 1$ 車いすの捉え方}

$4 \cdot 1 \cdot 1$ 車いす利用に関する高跉者の意識 調査 協力者が車い寸を利用しているか・利用していないかと いう現状は，車いすに対する印象に深く関わっていると 考えられる. また, その状況を満足しているか不満足か によって，つまり前向きに捉えることが可能（肯定的） か，前向きに捉えることができない（否定的）かによっ て，車いすの印象を判断することができる.

以降協力者の口述データから車いすの利用と意識 に関係する発言を引用し，それに関して分析する。 な お，引用は以下の様な形式で記した.

$$
\text { （協力者 ID）：引用文 （著者による補足） }
$$

$4 \cdot 1 \cdot 1 \cdot a$ 車いすを利用することに対する抵抗

（F）：だから自分では乗りたくない.こういうのに乗るんだ

Table 2 Fundamental profile (12 participants)

\begin{tabular}{|c|c|c|c|c|c|c|}
\hline ID & $\begin{array}{l}\text { Attril } \\
\text { ( sex, }\end{array}$ & oute & $\begin{array}{c}\text { Physical Status and } \\
\text { Disease }\end{array}$ & $\begin{array}{c}\text { Daily Life/ } \\
\text { Routine }\end{array}$ & $\begin{array}{l}\text { Care } \\
\text { Need } \\
\end{array}$ & $\begin{array}{l}\text { Experience in Use of Mobility Aids } \\
\text { (past/ now, years) }\end{array}$ \\
\hline A & Male & 82 & Gonalgia & Walking & NA & Bicycle (past) \\
\hline B & Male & 72 & Gonalgia & $\begin{array}{l}\text { Walking and } \\
\text { exercise everyday }\end{array}$ & NA & Bicycle (past) \\
\hline $\mathrm{C}$ & Male & 80 & Back pain & $\begin{array}{l}\text { Plays tennis until } \\
\text { he feel back pain }\end{array}$ & NA & $\begin{array}{l}\text { Walking-stick (now), } \\
\text { Bicycle (past) }\end{array}$ \\
\hline D & Female & & Broken hand & Walking & NA & Bicycle (past) \\
\hline E & Female & 84 & Healthy & Walking & NA & Bicycle (past) \\
\hline F & Female & & Healthy & Walking & NA & Bicycle (now) \\
\hline G & Female & & $\begin{array}{l}\text { Cerebral infarction, right } \\
\text { side hemiplegia }\end{array}$ & $\begin{array}{l}\text { Walking, Daily } \\
\text { service } 2 / \text { week }\end{array}$ & 1 & $\begin{array}{l}\text { Collator, Prosthetic with left foot } \\
\text { (now, over } 10 \mathrm{yrs} \text { ) } \\
\text { Wheelchair (past) }\end{array}$ \\
\hline $\mathrm{H}$ & Female & & $\begin{array}{l}\text { Cerebral infarction, right } \\
\text { side hemiplegia }\end{array}$ & $\begin{array}{l}\text { Daily service } \\
2 / \text { week }\end{array}$ & 3 & Wheelchair (now, 2-3 yrs) \\
\hline I & Female & 68 & $\begin{array}{l}\text { Cerebral infarction, } \\
\text { Heart disease, } \\
\text { Fracture, Leg paralysis } \\
\end{array}$ & $\begin{array}{l}\text { Daily service } \\
\text { 2/week }\end{array}$ & 2 & $\begin{array}{l}\text { Wheelchair (now, } 4 \text { yrs), } \\
\text { Stick (past, over } 10 \text { yrs) }\end{array}$ \\
\hline $\mathbf{J}$ & Male & 72 & Progressive impairment & $\begin{array}{l}\text { Daily service } \\
\text { 2/week }\end{array}$ & 3 & $\begin{array}{l}\text { Wheelchair (now, } 5 \text { yrs), } \\
\text { Powered wheelchair (past) }\end{array}$ \\
\hline $\mathrm{K}$ & Female & 85 & Subarachnoid bleeding & $\begin{array}{l}\text { Daily service } \\
2 / \text { week }\end{array}$ & 3 & $\begin{array}{l}\text { Rollator (now), } \\
\text { Wheelchair (now, over } 5 \text { yrs) }\end{array}$ \\
\hline $\mathrm{L}$ & Female & 94 & Stroke & $\begin{array}{l}\text { Daily service } \\
\text { 2/week }\end{array}$ & 1 & Wheelchair (now, over 10 yrs) \\
\hline
\end{tabular}


ったら外人は出ないな. 私は絶対に,もう.

(B)：いや, 想像しないねえ, 車いす乗るつて所まで想像 しないねえ. 寝込んじやうんじやないの?

（D）: (歩くことは)幸せだわね. 歩けなくなったらどうしまし よ. ねえ, もう, 落ち込んじやうね. 私きっとね, 歩けな 〈なったらね,わかんないその時になってみないとわ からないけれどね.もう外にはきつと出ないでしょ. 私 のことだから, 歩けなくなっちやったら.

（A）：(歩くことは) 健康維持もそれもあるけど, 気分転換 にもなるからね。

（F）：(歩くことは)健康の基/ 財産だなって思います。

車いすの非利用者 7 名中 6 名が，車いすに対して否 定的な印象を抱き，強い抵抗を示していた，また，将 来車いすの利用を想定することについても, 想像でき ない，考えないと強い抵抗を示しており，車いすに乗 ることに対して，否定的な印象が認められた。また， それに対応し, 歩けなくなることに対する不安も述べ られていた. それらは日頃の運動に気を使うことに結 びつき，車いすの非利用者 7 名中 7 名がウォーキング など何らかの運動を日課としていた. さらに, 歩くこ とを幸せ，健康維持，健康の基，財産と捉えていた。

(G) : (車小すは楽?)らん. 歩くのより楽/(気に入りました?) 気に入らないけどさあ/自分で一人で住むようになっ てから, やっぱり自分の足で行った方がいい／（車 いすは)足が弱っちやうからさ, だから歩くの.

一方で，以前車いすの利用経験はあるが，現在は利 用していない $\mathrm{G}$ は，車いすを利用することが歩くこと よりも楽であることを認識しているが, 自分の足で歩 くことを選択していた．また，車いすを利用すること によって，下肢機能を使わなくなり，下肢機能が低下 すると感じていた。

\section{4・1 1 1·b 車いすを利用することに対する満足感}

(H) : やっぱり外を見られて良かったなあっていら喜びば つかりですよ.

（I）：百点満点です.あれがなかったら全然外へも出ら れないもん。

(J) : 不満はないり 軽くてねえ

(K)：(車いすは) 自分の体みたいな物ね. 本当に, あれ (車いす)と一緒に住んでると思うのね. 自分の身体 の一部.

3 年以上の利用歴のある利用者は, 車いすに対する 不満はないと述べていた，そして，車いすをなくては ならない物, 外出を可能にする物, 身体の一部と捉え ていた. また, 利用経験のある 5 名中 5 名が利用の利 点を述べていた.

（L）:(車いす)私は乗りたくないですけど,ありがたいです からね.

（K）: 病院に行って, みんな乗っている姿は見てるけど, ああと思ったもんね. 実際自分で乗るとはさ, 考えて もいないし. 乗るとも思わなかったから.
（1）: 歩きたい. 歩いてます. 実際に, いくら(人に)やっ てもらいなさいって言っても, やっぱり自分で動かな いと惨めだもん.

脳梗塞の病歴がある L は, 日常生活は主に歩行器と 車いすを用いているが，車いすに対しては抵抗と感謝 の気持ちが混在することを述べていた，また，現在で は車いすは身体の一部であると感じている K は, 過去 に車いすを利用することになるとは思っておらず，初 めは何らかの抵抗があったと述べている. また，車い すの必要性を十分に感じているIに関しても, 歩けな いことが惨めであると述べている.

4.1.2 車いすに対する二つの視点 以上よ り，車いすに対し抵抗を感じる人と，満足してい る人が存在することがわかった，次に注目したの は，利用に対する否定的な意見や捉え方などを曖 昧な言葉で表現している点である。ここでは，車 いすに対する印象を, (1) 車いすそのものや利用者 に対する印象と, (2) 車いす利用者が利用する自己 を客観的な立場から見た印象の 2 つの特徵的な視 点に分類した.

\section{(1) 車いすと利用者に対する印象}

(J)：それはやはり，自分としてはかわいそうって言う ことを考えて. 気の毒だなあって.

（D）: (老老介助を見て)大変じやないかなあと思いま すよね.

（C）：本人の意思よりもね, 介護の一端として医療の ね. 回復する一端として, こうね，押させてるよう な, 連れて行くようなそんな感じを受ける.

(B) : リハビリとか, 病院, 病気上がりの人か? 病気 (リハビリに) 専念しているって感じだな. / 車い す借りて, その場限りの.

(2) 他者から見た自分 (車いす利用者) の印象

(K): 最初ね, 車いすになんか乗ってね, 恥ずかしい なあと思ってね, 知ってる人に会うとね, こっち (顔が見えない方向)向いてたの, 乗せてもらつ たけどね. 今, みんな知ってるからね, 何とも思 わなくなった.

（L）：本当にうごけなくてしゅーんとなってるんだった らね，しょうがないけど，見た目は元気そうでね， 車いすに乗ってるのは, 恥ずかしいですよね.

12 名中 10 名が車いす利用者はかわいそう, 気の毒, 大変そうという印象を持っていた. 車いすの利用経 験がないC は車いすに対し，人に押させる，連れて 行くといった受動的な機器である印象を抱いていた. また，Bについては車いすから医療や病気をイメー ジすることが述べられた.一方で, 車いす利用者は, 利用を始めた頃は, 知り合いに会うことを恥ずかし いと感じていることが述べられていた．また，片マ ヒにより歩行が困難だが，一見元気に見えるLは， 車いすに乗る自分が, 他人から車いすに乗るには元 気すぎると思われているのではないかと感じていた. 
$4 \cdot 1 \cdot 3$ 折り合いの付け方 以上より, 調查協 力者の中には，車いすをネガティブなものと捉える抵 抗感が認められた。この抵抗感に関し，利用者は何ら かの葛藤を感じながらも折り合いを付けていた. そこ で，この車いすに対するネガティブな印象を当事者が どのように考え, 葛藤にどのように対処したのかを, 協力者の車いすに対する印象や考えの変化から見て いくこととした.ここでは，それぞれのプロセスを丁 寧に迻つた.

（I）：(車いすを使い始めた頃)もちろん, 実際自分 でほら, 外行きたいし, 車いすで行こうって言わ れたとき,こんな便利なものあるんだって思って ね. あれ(利用)したんだけど, はじめはいやだと 思ったけど, もう, それがないと. / (何故いやだ と思った?)だって, 自分で元気なまま, まさか, 車いすであれ(生活)しようと思わないもん. 歩け たもの. / (歩けるのに使う必要はないじやないか という気持ち?)そうそう，もちろんそうよ. 体が不 自由になってやっとそういらの使おうってなって さ, 使うときも, ああ, 申し訳ないと思うわよ. 人の 手借りるんだもの. だけど, 今はないと生活でき ない. 感謝している. 車いすに. /うん. だんだん 不自由になってほら，立つこともだめだって言わ れると,こんなにありがたいと思っている.

（G）：(歩けることは) 幸せなことだ, 歩けない人, 歩きたく たって歩けない人もいるじやない. あたしはどんなに 遅くたって自分の足で歩くから幸せだと思う. / 歩け る人から見るとさ, まどろっこいなって思うけどさ, 私 は自分の足で歩〈から幸せ。

（H）：あこがれ，(歩ける頃は歩くこと) それが当然だと思っ ていた. /自分が摂生しなかったから悪いと原因の方 を思うと歩きたいなんて気にならない. /今, 生きてい るだけでもありがたいことだという風に思うようにして います.

車いすを利用する I は, 複数の疾患があり, 屋内で は杖と車いすによる生活を送っている. I は利用初期 に，これまで機器を利用することを考えたことがなく， 歩くことができたため, 機器を利用することに抵抗感 があった．しかし，利用を迫られ，実際に利用するこ とで, 活動範囲を広げることが可能と知り, 機器の利 便性を実感していると述べていた. また, $\mathrm{G}$ は以前車 いすを利用した経験があるが, 現在は屋外では歩行器 と装具による生活を行っており, 歩けない人（自分と 比べて障害が重度の者）と比較することによって自分 が歩けることを再認識し，歩けることが幸せであると 述べている. 一方，片マヒにより歩行が困難な $\mathrm{H}$ は， 歩くことができないことを，自分の不摂生に原因があ ると述へ，歩くことはあこがれであるが，生きている だけでもありがたいと述べている.

(C)：（杖を使う前は杖を持っている人のこと，自分も 使ってみたらどうかなどと)そういらことすら，考え たことないですね./自分が使ってみて,なるほ ど, 杖っていうのはありがたいな,てわかる./
(杖を使う人の見方が使用してから)変わったね 確かに変わった. あの人どうしたかなあ, 腰が痛 いかなあ，膝かなあとか，ああいら杖なのかな あ?ていらふうにね。

さらに, 杖についても同様の傾向がみられた.Cは, 腰痛のために調査日の直前に杖を利用することにな った. その際の杖の利用以前と利用以後についての, 印象の違いを述べていた。

\section{$4 \cdot 2$ 考察}

$4 \cdot 2 \cdot 1$ 車いす利用の意思 ここでは, 車い す非利用者 /利用者の車いす利用の意思を, 利用に 対する抵抗感や満足感から考察する. 非利用者は, 車いす利用に対して否定的に捉える場合が多く，そ の内容は，「利用により身体機能が低下する不安」

「歩くことが幸せ，健康である」「漠然とした利用 に対する抵抗感」に要約された。一方，利用者は， 車いすを肯定的に捉える場合が多く，「利便性が高 い」「身体の一部として」と認識していた。しかし， 利用者の中には，利用に対して満足をしていながら も，何らかの抵抗感があることを示した者もおり， 必ずしも完全に満足をしているわけではないことが わかった。

$4 \cdot 2 \cdot 2$ 車いすの印象と抵抗感次に, 車い す利用を否定的に捉えている者の中に存在した，漠 然とした抵抗感の詳細を, 車いすや車いす利用者に対 して持つ印象，車いすに乗る自己を客観的に見た印象 の 2 つの視点から考察する. 前者は車いすそのものが, 「身体機能の低下や障害を想像させる」「病院や老人 介護施設を想像させる」「介助者を想像させる」もの であると捉えていることがわかった，後者は，車いす を利用しているにもかかわらず，元気そうに見えるこ とが恥ずかしいことであると述べていた，つまり，

「車いすは障害や身体機能の低下した人が乗る物で ある」と捉える傾向があり, 利用者にはそのような振 る舞いをしなければならないのではないかという意 識があると考えられる.

$4 \cdot 2 \cdot 3$ 利用することで変化する機器の印象 調査協力者のうち, 車いすを利用している者は利 用に対する満足感と抵抗感に対する葛藤を, 利用し ていない者は身体機能の低下に対する不安と抵抗感 に対する葛藤を, それぞれの方法で消化し, 受け止め ていることがわかった. 利用者は, 結果的には移動す ることができることが大事である, とポジティブに受 け止めている場合でも，現状を受け入れる過程では， 過去への反省, 運命として受け止めるなどがあげられ ている. 一方で, 歩行移動を選択した高齢者は「歩け ることが幸せ」とポジティブな姿勢へと変化する過程 で, 自分より重度の障害のある歩行困難者と比較する ことで, 自分が歩けることの喜びを再認識している. 
つまり，調査協力者が現在の心境を説明する際に， 結果的には現状に満足しているという発言が得られ ても, 機器を利用するまでの過程には様々な葛藤を抱 えている可能性があるといえる. そして，高齢者は車 いすや杖の利便性を理解することで, 機器に対する印 象をポジティブに変化させていくと考えられる.この 機器に関する知識と利用の意思の関連性は, 白杖利用 者における調査からも同様の指摘がなされている ${ }^{(13)}$.

\section{5. 移動支援機器と高羚者の心理概念モデル}

5.1 プロセスの可視化 以上の調査結果から, 高齢者が日常生活の中で，身体機能の低下や車いすの 利用を受け入れていくプロセスを示す，心理概念モデ ルを作成した（図 3）。この概念モデルは，高齢者の 実体を把握しやすくするために，心理状況の変化のプ ロセスを可視化するものである. 調査結果を基に各要 素の関連性を整理することで, 問題点や要点を明確に 示すことができる.

$5 \cdot 2$ 身体機能の 2 つの側面と車いす 4 章の結果 から，車いすを利用する際に見受けられた葛藤，抵抗， 折り合いなどの感情は，2 つの二律背反（ジレンマ）と して説明することができる．それは，ジレンマ A. 車い すを利用すれば移動が可能となるが，身体機能が低下す る可能性がある(Between body function and mobility activity), ジレンマB. 車いすに座ることは楽であるが, 障害者として扱われる可能性がある(Between body appearance and effortless mobility), ことである. つまり, 車いすの利用と身体機能の維持の間には，身体機能その ものに対する問題と, 身体機能の表象に関する問題の 2 つの問題が存在し，これらが車いすを利用する際の葛藤 の原因となる.

\section{$5 \cdot 3$ 葛藤と折り合い}

\section{$5 \cdot 3 \cdot 1$ 葛藤 ジレンマ}

A. によって生じる葛藤は, 身体 機能の低下を実感する高齢者が 直面する抵抗感である. 次に, 高 齢者が身体機能の低下によって, 車いすの利用を迫られる状況に なると, ジレンマB. 車いすに乗 ることで, 体の不自由な人と見ら れることに対する新たな抵抗感 が生じる.また, 車いすが病院や 老人介護施設を連想させる場合 もあり,これらも抵抗感の要因と なる. そして, それらの車いすに 対するネガティブな印象は, 高齢
者が車いすを利用していなかった時点で持つ車いすの 印象に依存し，車いすに乗っている人の印象と，車い すに乗ることになる自分の間にギャップを感じ，葛藤 が生ずる.

$5 \cdot 3 \cdot 2$ 折り合い 車い寸非利用者は, 身体 機能の低下が日常生活に支障をおよぼす恐れに対し， 身体機能を維持するために運動をすることで, この 葛藤を軽減しようとする，車いす利用者は，車いす を利用することになると, 利用することになったの は，自分の不摂生のせいであることや，生きていく だけでも幸せであるという考え方をし，移動するこ との利点を重視するようになり，納得していく．ま た，車いすの利用経験があるが歩くことを選択した 高齢者は, 自分より重度の障害のある人と比較する ことで, 歩けることの重要性を再認識する.さらに, 多少歩行が困難であっても，歩けることは幸せであ ると思考を転換することで，その状況を納得してい $<$.

\section{$5 \cdot 3 \cdot 3$ モデルの特徵 これまで, 福祉機器} の利用評価の研究分野では, 機器を利用することで 何が変化したかを示す概念モデルが多数報告されて いる. その中でも, 福祉機器に対する意識と利用の 関係を示したRoelands らの高齢者の福祉機器利用モ デル ${ }^{(14)}$ は，本モデルと同様の視点を持つ社会認知 モデルの一つである. 本研究で構築したモデルは, Roelands らのモデルと同様に, 機器の利用者に対す る心理的な状況を把握することが可能である. それ に加えて，本モデルでは，利用者が抱く機器に対す る心理的なトレードオフの関係を明示する構成にし たことで，機器に必要な要件を導くことができるよ うになり, 機器開発へ応用することが容易となる.
Dilemma A. Between body function and mobility activity

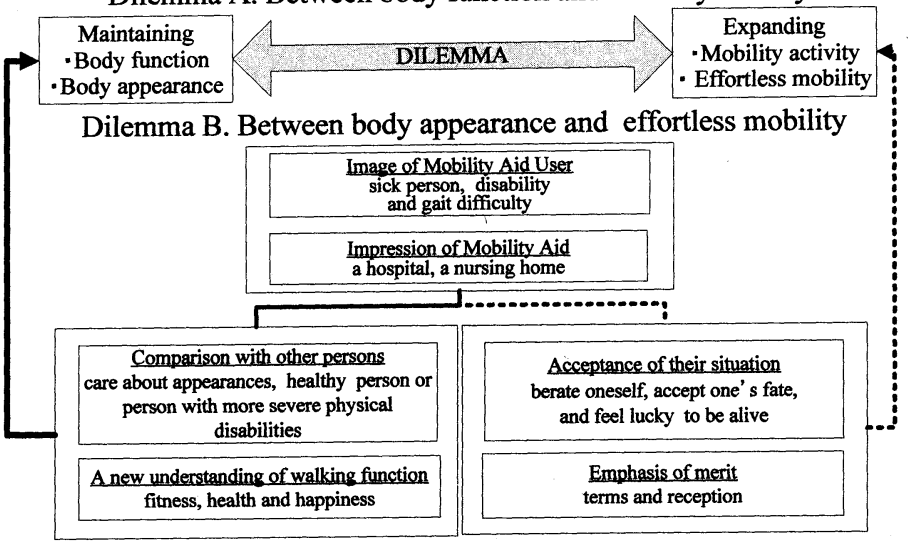

Fig. 3 The dilemma resolving process model of older persons 
また，本モデルを，車いす（福祉機器）を利用し 始めるプロセスに当てはめると，供給された福祉機 器の不利用に関するWessels らの報告 ${ }^{(15)} に よ り$ 示さ れた，障害受容のプロセスは福祉機器の利用に大き く影響されること，患者が機器を利用するかは本人 が自分自身および福祉機器に抱く期待に影響される こと，を説明可能である．したがって，本モデルを 本研究で取り扱った身体機能の衰えを自覚しており， それに対して折り合いをつけて生活していかなけれ ばならない高齢者を対象とした, 移動支援機器の開 発に適用することは妥当であると考えられる。

\section{6. 開発要件の抽出}

$6 \cdot 1$ 開発要件 5 章より, 車いすの利用を迫られた 高齢者の心理的なストレスの要因が『身体機能の低下』, 『移動活動の低下』，『障害者として見られることに対 する抵抗感』であることがわかった。しかし，高齢者の 抱くジレンマは, 加齢による機能低下が起こるために完 全になくなることはない.したがって，このようなジレ ンマを抱える高齢者に移動支援機器を導入するためには, 使用者の心理的な抵抗感や葛藤を軽減し，折り合いを付 けやすい機器を開発することが開発要件となる.つまり， 「身体機能の維持」や「移動活動の維持・拡大」，「他 者の視点から見た歩行姿勢の維持」を考慮することが, 高齢者の移動支援機器に対する抵抗感の軽減に有効であ ると考えられる.

ここで,これらの 3 つの要件を以下のように定義し, 同時に解決することを要件とした. それらはそれぞれ,

（1）身体機能の維持は，生体内で発生する移動 (歩行) 時に必要な筋や関節の運動を維持すること，（2）移動 範囲の維持・拡大は, 日常・社会生活における行動・移 動範井を維持・拡張すること, （3）他者の視点から見 た歩行姿勢は，特別な姿勢や動作を指示することなく， 自由で自然な姿勢や歩容を示すこと，である.

\section{2 機器開発の応用例 著者らは, 本調査によ}

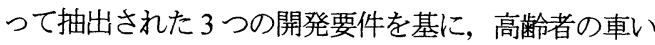
す利用に対する心理的な抵抗感の軽減を図った機器 開発を行った ${ }^{(1)}$. 図 4 に要求機能を明確化するための プロセスを示す.はじめに, 具体的な開発対象として, 歩行が可能な利用者であることを前提とし，前述の開 発要件から要求機能を求めた。 ここでは, 身体的な要 素と機械的な要素を分類し, 機器構成を具体化した. 身体的な要素は歩行による移動機能・歩く姿である表 象・歩行運動を行う際の感覚に分類し, それぞれの要 素を実現する機械構成を移動機能・機器形状・操作系 との対応付けを行い, 要求機能を決定した. 開発した

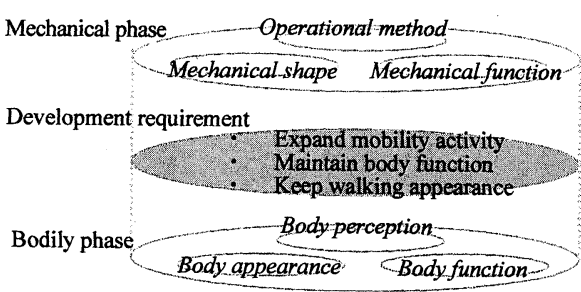

Fig. 4 Development requirement between bodily and structural phase

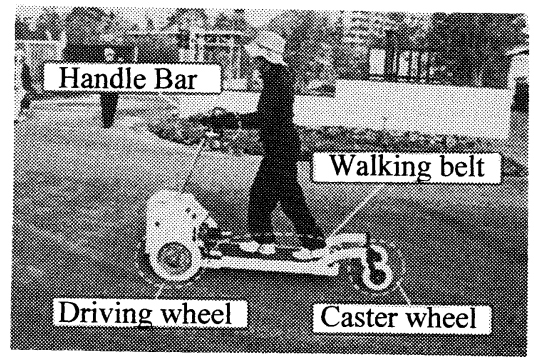

Fig. 5 One example of development: Tread Walk

機器（図 5）は，歩行時に必要な筋や関節の運動を維 持し, 移動範囲を維持・拡張させ, 自然歩行を行うだ けで操作が可能な移動支援機器である. 機器構成は, DC モー夕に接続された 1 枚のベルトに与えた力を検 出し, それを入力信号として, ベルトの回転速度の制 御を行う.さらに, そのトレッドミルの速度情報を車 輪型の移動機器の駆動指令として用いることで, 歩行 速度に比例したゲインを与えた走行を可能にする. そ れにより,『身体機能の維持』, 『移動距離の拡大』, 『歩行が可能な人である姿を示すこと』の機能を実現 した. 本機を用いて今後, 利用評価を行い, 心理的な 影響の調查と確認を行う予定である.

6.3 概念設計と質的研究アプローチ 車いすの利 用と身体機能に関するジレンマは, 環境的・身体的な 不便の問題として当事者が開発者に伝えることが可 能である.しかし，本調查で確認した身体機能のもう 一つの側面である表象に関わるジレンマは，これまで の機器開発においては重要視されてこなかった. この ジレンマは, 内生的な現象であり, 複雑な構造を持つ ため, 定量化が難しい. 特に, 当事者が葛藤に苦しみ, 恥ずかしさやあきらめを感じながら折り合いを付け ていくプロセスは，個人の努力により意識的・無意識 的に隠されるものであり, 当事者側から積極的に語ら れることはほとんどない，そのため，これまでこのよ うな心理的な問題は, 開発者には伝わらないことが多 く，新たな機器を開発するモチベーションとはなりに くかった。 
本研究では，質的研究アプローチを用い，当事者の 機器利用の阻害要因となる心理的なストレスを把握 し，プロセスを可視化した．つまり，本アプローチを 用いることで，開発者が当事者の深い情報を理解し， 個人の持つ問題の相違点や共通点を当事者の視点か ら取り込み，共有化することができる.

本調査により作成されたモデルは，調査協力者とな る 12 名の高齢者の調査結果を反映したモデルである. そのため, すべての高齢者を包含したものではないが, 一部の高齢者の現実的な状況における代表例として 捉えることが可能である.これによって，これまで高 齢社会における人口分類として画一的に捉えられて きた高齢者の現状を，より深く捉えることができた.

\section{7. 結 言}

本研究では，在宅生活をする高齢者を対象に，移動 支援機器の捉え方や機器に対する印象の調査を行っ た. 調査の結果, 機器利用の阻害要因として, 車いす に対する心理的な抵抗感の存在が示された。この抵抗 感の詳細を明らかにするために, 発生プロセスを調べ, それらを可視化するための概念的なモデルを作成し た. さらに，このモデルを基に，抵抗感を軽減するた めの新たな移動支援機器の開発要件の提案を行った. その結果，以下の結論が得られた.

（1）質的研究アプローチを用いた調査により，車い すを利用する際には，身体の機能と表象に関する2つ のジレンマが発生することがわかった.

（2）機器を利用することで生じる表象に関するジレ ンマにより発生する抵抗感は, 自然な歩行姿勢や動作 が可能である姿を示すことで軽減する可能性があるこ とがわかった。

（3）抵抗感の詳細と発生プロセスをモデル化するこ とで，質的な言語データから得られた内生的な現象を 可視化し, 移動と身体機能と身体表象の 3 つ観点を 総合的に取り込んだ，開発要件を抽出した.

今回明らかになった車いすに対する抵抗感のよう な, 個人の内面に生じる精神的な問題は, 使用者の立 場に立つた機器を開発する上で，無視することのでき ない問題である. また, 当事者の心理状況において機 器に対する印象が変化することが認められたことは, 機器開発プロセスにおいて, 生活状況や身体状況に心 理状況を加えた複合的な分析手法が必要であること を示しており，そのような分析手法を用いることで， より有用な機器開発が期待される.

\section{謝 辞}

本調査に協力いただいた被験者の方々に，ここに記 して感謝の意を表す。

本研究の一部は, 日本学術振興会 21 世紀 COE プロ グラム「超高齢社会における人とロボット技術の共

生」, 文部科学省科学技術振興調整費戦略的研究拠点 プログラム「先端科学と健康医療の融合研究拠点の形 成」の支援を受けて行われた。

\section{文献}

(1) Masahiro K., For the Creation of New Market of the Aged Society with a Fewer Number of Children, Journal of the Japan Society of Mechanical Engineers, Vol. 108, No. 1038 (2005), pp.37-42.

(2) Inoue T., et al., Development of Head Controlled Powered Wheelchair Based on Components of QOL, Wellbeing Science and Assistive Technology, Vol. 11, No. 1 (2002), pp.42-48.

(3) Tsukada A., et al., Bottlenecks and their Solutions for Development of Assistive Technologies (Based on Development Process of 10 ATs), Transactions of the Japan Society of Mechanical Engineers, Series C, 68-675 (2002), pp.303-310.

(4) Inoue K., et al., Psychological Gerontology (in Japanese), (2002), Asakura Shoten, pp.13-17.

(5) Wessels R., et al., Non-use of Provided Assistive Technology Devices, a Literature Overview, Technology and Disability 15, (2003), pp.231-238.

(6) Nakazawa H., Development Design Engineering (in Japanese), (2001), pp.13-16, Kogyo Chosakai Publishing Inc.

(7) Uwe F., Qualitative Forschung, (2003), pp. 3-20, Shunjusha.

(8) Minoura Y., The Technique and Application of Fieldwork -Introduction to Micro-Ethnography- (in Japanese), (1999), MINERUVA Publishing.

(9) The Association for Technical Aids, Technical aids for persons with disabilities -Classification and terminology-, ATA (2002), pp.53-58.

(10) Baker D.J., et al., Acceptance and Meanings of Wheelchair Use in Senior Stroke Survivors, American journal of occupational therapy, Vol.58, No.2 (2004), pp.221-230.

(11) Deborah L., et al., Technology, Selfhood and Physical Disability, Social Science \& Medicine, 50 (2000), pp.1851-1862.

(12) Lofland J\&L., Analyzing Social Setting, (2004), pp.243-276, Kouseisha Kouseikaku.

(13) Takata A., Research on the Use of a Long Cane by People with Acquired Visual Impairment - A Mail in Questionnaire Research to Grasp the State of Actual Usage and Their Mind-, Japanese Journal of Social Welfare, 43-2 (2004), pp.125-136.

(14) Lenker J. A., et al., A Review of Conceptual Models for Assistive Technology Outcomes Research and Practice, Assistive Technology (RESNA), 15 (2003), pp.1-15.

(15) Wessels R., et al., Non-use of provided assistive technology devices, a literature overview, Technology and Disability 15 (2003), pp.231-238.

(16) Nihei M., et al., A Hybrid Manual/Motorized Mobility Device for Assisted Walking, Biomechanism 18 (2006), pp.101-111. 